\title{
Alt Solunum Yolu Enfeksiyonu Geçiren 1-24 Ay Arası Çocuklarda Serum 25(OH)D Vitamini Düzeyleri
}

\section{Serum 25(OH) Vitamin D Levels in Children Between 1 to 24 Months of Age with Previous Lower Respiratory Tract Infection}

\author{
Nihal Aydın (D), Mustafa Özçetinn ${ }^{2,3}$ (D), Ali Aydın ${ }^{4}$ (D), Nedim Samancı ${ }^{5}$ (D), Yakup Çağ ${ }^{6}$ (D)
}

${ }^{1}$ Bezmialem Vakıf Üniversitesi, Çocuk Nörolojisi Bilim Dalı, İstanbul, Türkiye

${ }^{2}$ ístanbul Üniversitesi, İstanbul Tıp Fakültesi, Çocuk Sağlığı ve Hastalıkları Anabilim Dalı, İstanbul, Türkiye

${ }^{3}$ Istanbul Üniversitesi, Çocuk Sağlığı Enstitüsü, Aile Sağlığı Anabilim Dalı, İstanbul, Türkiye

${ }^{4}$ Süleymaniye Eğitim ve Araştırma Hastanesi, Çocuk Nörolojisi Bilim Dalı, İstanbul, Türkiye

${ }^{5}$ Namık Kemal Üniversitesi, Çocuk Sağlığı ve Hastalıkları Anabilim Dalı, Tekirdağ, Türkiye

${ }^{6}$ Sağlık Bilimleri Üniversitesi, Dr. Lütfi Kırdar Kartal Eğitim ve Araştırma Hastanesi, Çocuk Sağlığı ve Hastalıkları Anabilim Dalı, İstanbul, Türkiye

ORCID ID: N.A. 0000-0003-3384-1677; M.Ö. 0000-0003-0697-4271; A.A. 0000-0002-9764-3293; N.S. 0000-0002-3947-3492; Y.Ç. 0000-0002-3855-7280

Attf/Citation: Aydin N, Ozcetin M, Aydin A, Samanci N, Cag Y. Alt solunum yolu enfeksiyonu geçiren 1-24 ay arası çocuklarda serum 25(OH)D vitamini düzeyleri. Çocuk Dergisi - Journal of Child 2020;20(1):7-12. https://doi.org/10.26650/10.26650/jchild.2020.1.0002

ÖZ

Amaç: Bu çalışmada; 1-24 ay arası çocuklarda serum D vitamini düzeylerinin alt solunum yolu enfeksiyonu (ASYE) ile ilişkisinin araştırılması amaçlanmıştır.

Gereç ve Yöntem: Eylül 2010 ile Eylül 2013 tarihleri arasında, hastanemizin çocuk polikliniklerine başvuran 1-24 ay arası ASYE tanısı alan 31 hasta çocuk ile aynı yaş grubunda kronik hastalığı olmayan ve ASYE geçirmeyen 33 çocuk olmak üzere toplam 64 çocuk alındı. Hastaların ve kontrol grubundaki olguların serum 25(OH)D vitamini düzeyleri ELISA yöntemiyle ölçüldü. Bulgular: Çalışmamızda; alt solunum yolu enfeksiyonu geçiren çocukların serum 25(OH)D vitamini düzeyleri kontrol grubuna göre daha düşük bulun$d u(p<0,001)$. Gebelik boyunca annenin ve sonrasında bebeklerin düzenli $D$ vitamini kullanımı ile ASYE arasında anlamlı bir ilişki saptandı. Annenin giyim şekli, çocuğun anne sütü alımı, dışarıda zaman geçirme süresi, cinsiyeti ve ASYE geçirme sayısı ile serum 25(OH)D vitamini arasında anlamlı bir ilişki saptanmadı.

Tartışma: ASYE geçiren 1-24 ay arası çocukların serum 25(OH)D vitamini düzeyleri sağlıklı çocuklara göre anlamlı olarak düşük bulunmuştur. Sonuç: Enfeksiyonlara karşı savunmada önemli rolü olan D vitamininin hangi düzeyin altında savunma sistemini zayıflattığını belirleyebilmek için vaka sayısının daha fazla olduğu klinik-etkinlik araştırmalarına ihtiyaç vardır.

Anahtar Kelimeler: Alt solunum yolu enfeksiyonu, D vitamini, süt çocuğu
ABSTRACT

Objective: The aim of this study was to investigate the relationship between lower respiratory tract infection (LRTI) and the level of serum vitamin D in infants aged 1-24 months.

Material and Method: The sample in this study included a total of 64 infants consisting of 31 infants aged 1 to 24 months and diagnosed with LRTI at the pediatric policlinics of our hospital and 33 infants of the same age range and diagnosed with neither a chronic disease nor LRTI. The levels of serum $25(\mathrm{OH})$ vitamin $D$ in patients and cases in control group were measured with ELISA.

Results: In the study, it was found that levels of serum $25(\mathrm{OH})$ vitamin D in patients with LRTI were lower than control group $(p<0.001)$. A significant relationship was found between LRTI and regular use of vitamin D by the mother during pregnancy and by the baby postnatally. A significant relationship was not found between serum $25(\mathrm{OH})$ vitamin $D$ and the clothing style of mother, breastfeeding, time spent outdoors, sex, or number of instances of LRTI.

Discussion: The levels of serum $25(\mathrm{OH})$ vitamin $D$ in infants aged 1-24 months with LRTI was found to be significantly low compared to healthy infants.

Conclusion: There is a need for clinical effectiveness studies with a higher number of cases in order to determine under which level of the vitamin D, which plays a critical role in defense against infections, weakens the defense system.

Keywords: Lower respiratory tract infection, Vitamin D, infant

Sorumlu Yazar/Corresponding Author: Nihal Aydın E-mail: nihalsoylutp@hotmail.com

Başvuru/Submitted: 23.09.2019 • Revizyon Talebi/Revision Requested: 17.01.2020 • Son Revizyon/Last Revision Received: 20.03 .2020 • Kabul/Accepted: 25.03.2020 


\section{GíRiş}

Alt solunum yolu enfeksiyonları (ASYE) bronşiolit, bronkopnömoni ve pnömoni tanılarını ifade eden bir tanımlama olup, çocukluk döneminin en önemli morbidite ve mortalite nedenlerinden biridir $(1,2)$. Alt solunum yolu enfeksiyonlarının en çok görüldüğü yaş yaşamın ilk 5 yılıdır. ASYE pediatri servislerine ve çocuk yoğun bakım ünitelerine hasta yatı̧larııın en sık sebeplerini oluşturmaktadır (3). Dünya Sağlık Örgütü'nün 2015 yılı raporuna göre ASYE tüm dünyada 5 yaş alt çocuk ölümlerinin \%15'inden Türkiye'de ise \%9'undan sorumlu olduğu bildirilmiştir. Prematürelik, düşük doğum ağılığı, 2 yaş alt olmak, kronik hastalık, düşük sosyoekonomik düzey, kalabalık ortam, kış mevsimi, sağılık hizmetlerine ulaşamama, hava kirliliği ve yetersiz bağışıllama, anne sütü alamama, malnütrisyon ve $D$ vitamini eksikliği ASYE için başlıca risk faktörleridir (4).

Vücutta çoğu doku ve hücrelerin $D$ vitaminin aktif formu olan 1,25(OH)D bulundurmasının anlaşılmasıyla, vitamin D'nin pek çok biyolojik fonksiyonları araştıılmaya başlanmıştr. Kemik dışında hemen her hücrede (beyin, kalp, mide, pankreas, deri, meme, gonadlar, T ve B lenfositleri, monositler, akciğerler vs.) vitamin $D$ reseptörü (VDR) tespit edilmesi ile $D$ vitamininin kemik metabolizması dışındaki diğer dokuların fonksiyonlarında da önemli rolü olduğu ve pek çok hastalıkla ilişkili olabileceği düşünülmektedir (4). D vitamini ile ilgili reseptörlerinin $T$ ve $B$ lenfositler, makrofajlar ve dendritik hücreler gibi özellikle antijen sunan hücreler olmak üzere tüm immün sistem hücrelerinde bulunduğu saptanmıştr $(5,6)$. D vitamininin makrofajların ve naturel killer hücrelerinin fagositoz aktivitesini arttrdığı bilinmektedir (7). D vitamini eksikliğinde daha güçlü T helper 1 cevabına bağlı olarak proinflamatuar sitokinlerin sentezi (interferon-gamma (IFN- $\gamma$ ), interlökin- 2 (IL-2), tümör nekrotizan faktör-alfa (TNF- $\alpha$ ) ) artar. Bunun sonucunda immün yanıt bozulur ve enfeksiyonlara eğilim artar (8-10).

Hem D vitamini eksikliği hem de ASYE ülkemiz gibi gelişmekte olan ülkelerde önemli halk sağlığı sorunlarıdır. Ülkemizde çocuklarda ASYE ve D vitamini ilişkisini inceleyen çalışmalar sınırlıdır. Bu çalışmamızda; ASYE geçiren 1-24 ay arası çocuklar ile daha önce ASYE geçirmeyen 1-24 ay arası sağlam çocukların serum 25(OH)D vitamini düzeylerini karşılaştrarak ASYE ile ilişkisini araştırmayı amaçladık.

\section{GEREÇ VE YÖNTEM}

Çalışmaya Eylül 2010 ile Eylül 2013 tarihleri arasında, yerel etik kurulu onayı (2013/154) alındıktan sonra, çocuk polikliniğine başvuran 1 ay-24 ay arası ASYE tanısı alan 31 hasta çocuk ile aynı yaş grubunda çocuk polikliniğine başvuran, kronik hastalığı olmayan ve ASYE geçirmeyen 33 çocuk olmak üzere toplam 64 çocuk alındı. Çalışmaya alınan tüm çocukların ebeveynlerinden yazılı onam alındı. Hastalardan klinik ve laboratuvar bulgularına göre bronşiolit, bronkopnömoni ve pnömoni tanıları alanlar ASYE olarak kabul edildi.

ASYE tanısı alan 31 hastanın; 25(OH)D vitamini düzeyi, o dönemdeki yaşı, vücut ağırlığı, boyu, kaç defa ASYE tanısı aldığı, doğum tartsıı, annenin gebe iken D vitamini kullanımı, annenin emzirme döneminde D vitamini kullanımı, annenin giyim şekli, çocuğun ne kadar süre sadece anne sütü ile beslendiği, toplam anne sütü aldığı süre, günde en az 400 IU D vitamini düzenli kullanımı, en az bir yıl süre ile $D$ vitamini düzenli kullanımı ve çocuğun haftada hangi sıkıkla dışarıda vakit geçirdiği sorgulandı. Aynı dönemde hastanemiz sağlam çocuk polikliniğine başvurmuş ve alt solunum yolu enfeksiyonu geçirmemiş 1-24 ay arası 33 çocuk kontrol grubunu oluşturdu. Çalışmaya dahil edilen tüm anne ve çocukların $D$ vitamini kullanım süreleri sorgulandıktan sonra $25(\mathrm{OH}) \mathrm{D}$ vitamini düzeyleri ölçüldü. Erken doğum öyküsü olan, beslenme yetersizliği ya da kronik hastalığı olan, alt aydan az anne sütü alan, aşıları eksik olan, evde soba ya da açık ateşle ısınan, evde sigara içimi olan, kalabalık yaşam koşulları olan çocuklar çalışmaya alınmadı. Ayrıca ailesinde atopik dermatit, astım, alerjik rinit gibi hastalık öyküsü olanlar çalışma dışında tutuldu.

25(OH)D vitamin düzeyi Elecsys 2010 cihazında, ECLIA (Elektro kemilüminesans immünolojik test) yöntemi ile çalışıldı. Sonuçlar $\mathrm{ng} / \mathrm{mL}$ olarak verildi. $25(\mathrm{OH}) \mathrm{D}$ vitamini düzeyi $<20 \mathrm{ng} / \mathrm{mL}$ D vitamini eksikliği, 21-32 $\mathrm{ng} / \mathrm{mL}$ D vitamini yetersizliği, $>32$ $\mathrm{ng} / \mathrm{mL}$ normal, $>150-200 \mathrm{ng} / \mathrm{mL}$ zehirlenme olarak kabul edildi (11). D vitamini çalışılması için kanlar hastalar hastaneye başvurduğunda alındı, $-40^{\circ} \mathrm{C}^{\prime}$ de saklandı. Çalışma sonunda tüm kan örneklerinde $D$ vitamini düzeyi topluca çalışıldı.

\section{İstatistik Analiz}

Veriler, SSPS (Statistical Package for the Social Science, Inc.; Chicago, IL, ABD) 21,0 paket programına kaydedilerek istatistiksel çözümlemeleri yapıldı. Tanımlayııı istatistikler; kategorik değişkenler için sayı ve yüzde, sayısal değişkenler için ortalama, standart sapma, ortanca, minumum ve maksimum olarak verildi. Hasta ve kontrol gruplarının değerlerinin karşılaştırıımasında Student - $t$ testi, Mann Whitney U testi ve Ki-Kare önemlilik testi kullanıldı. Ölçüm değişkenlerinde normal dağılıma uygunluk testi yapıldı, normal dağılıma uymadığında nonparametrik testler kullanıldı (Kolmogorov-Smirnov / Shapiro-Wilk). İstatistiksel anlamlılık düzeyi $p$ değerinin 0,05 ten küçük olması durumu olarak kabul edildi.

\section{BULGULAR}

Çalışma grubuna alınan 23'ü (\%74) erkek 31 çocuğun yaşları ortalaması $12,55 \pm 3,713$ ay, kontrol grubuna alınan 24 'ü (\%73) erkek 33 çocuğun yaşları ortalaması ise $11,97 \pm 3,957$ ay idi. (Tablo 1). Çalışma ve kontrol grubu arasında cinsiyet, yaş, kilo, boy, doğum tartısı, yalnız anne sütü kullanımı ve toplam anne sütü kullanımı açııından fark saptanmadı $(p>0,05)$. Bu değerler birbirine oldukça benzerdi (Tablo 1). Çalışma grubunun ortalama $25(\mathrm{OH}) \mathrm{D}$ vitamini düzeyi kontrol grubuna göre istatistiksel olarak anlamlı fark olacak şekilde daha düşük bulundu $(p<0,001)$ (Tablo 1).

Çalışma grubunun ASYE geçirme sayısı olarak; bir kez ASYE geçirenler \%58, iki kez ASYE geçirenler \%29, üç kez ASYE geçirenler $\% 6,5$ ve dört kez ASYE geçirenler \%6,5 olarak saptandı. Bir kez ASYE geçirenlerin ortalama 25(OH)D vitamini düzeyi

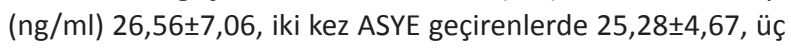


kez ASYE geçirenlerde 27,65 $\pm 2,19$, dört kez ASYE geçirenlerde $29,25 \pm 6,29$ olarak tespit edilmiştir. Yapılan analizde ASYE geçirme sayısı ile vitamin düzeyleri arasında istatiksel olarak anlamlı bir fark bulunmadı $(p>0,05)$.

Çalışma grubunun \%51,6'sının annesi D vitaminini gebelik boyunca düzenli kullanmış, \%32,3'ü düzensiz D vitamini kullanmış, $\% 16,1^{\prime} i$ ise hiç D vitamini kullanmamışt. Annelerin \%83,9'u geleneksel giyim tarzı şeklinde güneş ışınlarından faydalanamayacak şekilde giyiniyordu. Olguların \%58,1'i bir yıldan daha az süre ile günde en az 400 IU D vitamini düzenli olarak kullanıyorken, $\% 25,8^{\prime} i$ en az bir yıl süre ile düzenli D vitamini kullanmışt. Kontrol grubunda ise annelerin $\% 60,6$ 'sı gebelik süresince düzenli, $\% 12,1$ 'i düzensiz D vitamini alırken, \%27,3'ünün hiç almadığı tespit edilmiştir. Annelerin \%78,8'i geleneksel tarzda giyiniyordu. Çocukların \%54,5’i bir yıldan daha az süre ile günlük en az
400 IU düzenli olarak D vitamini kullanıyordu. $\% 21,2$ 'si en az bir yıl boyunca düzenli $D$ vitamini kullanmışt (Tablo 2).

Çalışma grubundaki annelerin ancak yarısı $(\% 51,6)$ gebelik boyunca düzenli D vitamini kullanmışlardı ve bu gruptaki çocukların ortalama $25(\mathrm{OH}) \mathrm{D}$ vitamini düzeyleri kontrol grubuna göre anlamlı olarak düşük bulundu ( $p=0,0001)$ (Tablo 3). Çalışma ve kontrol grubunda günlük en az 400 IU düzenli D vitamini kullanımı ile $25(\mathrm{OH}) \mathrm{D}$ vitamini düzeyi arasında da anlamlı olarak fark bulundu $(p=0,002)$ (Tablo 4$)$.

Çalışma grubunda, kontrol grubunda ve tüm gruplarda cinsiyet, annenin giyim şekli, yalnız anne sütü alma süresi, toplam anne sütü alma süresi, dışarıda zaman geçirme sıklığı ile 25(OH)D vitamini arasında istatistiksel olarak anlamlı fark bulunmadı $(p>0,05)$.

Tablo 1: Çalışma ve kontrol gruplarının demografik yapıları, anne sütü alma süreleri, 25(OH)D vitamin düzeyleri

\begin{tabular}{|c|c|c|c|}
\hline & 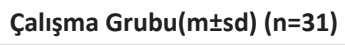 & Kontrol Grubu(m $\pm s d)(n=33)$ & $\mathbf{p}$ \\
\hline Erkek cinsiyet [n (\%)] & $23(74)$ & $24(73)$ & 0,894 \\
\hline Doğum tartısı (gr) & $3293,87 \pm 428,903$ & $3283,64 \pm 462,836$ & 0,927 \\
\hline Yaş (ay) & $12,55 \pm 3,713$ & $11,97 \pm 3,957$ & 0,549 \\
\hline Boy $(\mathrm{cm})$ & $76,52 \pm 5,026$ & $76,12 \pm 5,946$ & 0,776 \\
\hline Anne sütü alma süresi (ay) & $10,19 \pm 3,260$ & $10,03 \pm 4,448$ & 0,807 \\
\hline Yalnız anne sütü alma süresi (ay) & $5,16 \pm 1,036$ & $4,79 \pm 1,556$ & 0,415 \\
\hline 25(OH)D vitamini düzeyi (ng/ml) & $26,43 \pm 6,051$ & $37,88 \pm 13,436$ & 0,0001 \\
\hline
\end{tabular}

Tablo 2: Çalışma ve kontrol grubu annelerin hamilelikte D vitamini kullanımı ve giyim şekli ile çocukların günlük D vitamini kullanımı

\begin{tabular}{|c|c|c|c|}
\hline & & Çalışma Grubu n (\%) & Kontrol Grubu n (\%) \\
\hline \multirow[t]{3}{*}{ Hamilelikte D vitamini kullanımı } & Düzenli kullananlar & $16(51,6)$ & $20(60,6)$ \\
\hline & Düzensiz kullananlar & $10(32,3)$ & $4(12,1)$ \\
\hline & Hiç kullanmayanlar & $5(16,1)$ & $9(27,3)$ \\
\hline Günlük (400 IU/day) Düzenli D vitamini kullanım & En az 1 yıl ve daha fazla & $8(25,8)$ & $7(21,2)$ \\
\hline \multirow[t]{2}{*}{ Anne giyim şekli } & Geleneksel giyim & $26(83,9)$ & $26(78,8)$ \\
\hline & Modern giyim & $5(16,1)$ & $7(21,2)$ \\
\hline
\end{tabular}

Tablo 3: Çalışma ve kontrol grubunda gebelik boyunca düzenli D vitamini kullanan annelerin çocuklarında ortalama 25(OH)D vitamini düzeyleri

\begin{tabular}{lccc}
\hline & Çalışma grubu & Kontrol grubu & p \\
\hline Çocukların 25(OH)D vitamini düzeyleri & $28,24 \pm 5,068$ & $41,31 \pm 14,153$ & 0,0001 \\
\hline
\end{tabular}

Tablo 4: Çalışma ve kontrol grubunda günlük en az 400 IU düzenli D vitamini kullanan çocukların serum 25(OH)D vitamini düzeyi

\begin{tabular}{lcc}
\hline & Çalışma grubu & Kontrol grubu \\
\hline Çocukların 25(OH)D vitamini düzeyleri & $29,14 \pm 5,34$ & $45,44 \pm 11,827$ \\
\hline
\end{tabular}




\section{TARTIŞMA}

Alt solunum yolu enfeksiyonları kasım ve mart ayları arasında daha sık görülmektedir. Ayrıca D vitamini eksikliği de bu zaman diliminde yetersiz UV ışınlarının alımı nedeni ile artmaktadır. D vitamininin immün sistemdeki etkileri nedeni ile mikroorganizmaların neden olduğu enfeksiyonların engellenmesine yardımcı olduğu bilinmektedir. Bu konuda yapılan bazı çalışmaların ortak sonucu olarak; 25(OH)D vitaminin kalsiyum metabolizması dışında farklı fonksiyonlarının olduğu, D vitamini eksikliğinin enfeksiyonlara zemin hazırladığı ve bu bulguların iskelet sistemi bulgularından daha önce ortaya çıktığı söylenebilir (10-12). Bu çalışmada da ASYE geçiren 1-24 ay arası çocukların serum $25(\mathrm{OH})$ D vitamini düzeyleri sağlıklı çocuklara göre anlamlı olarak düşük bulunmuştur. Annenin gebeliğinde $D$ vitamini kullanımı ve çocuğun günlük en az 400 IU D vitamini düzenli kullanımı çocukların serum 25(OH)D vitamini düzeyi ile anlamlı derecede ilişkilidir. Annenin giyim şekli, yalnız anne sütü alma süresi, toplam anne sütü alma süresi, 1 yıl süre ile düzenli $D$ vitamini kullanımı ve dışarıdaki vakit geçirme sıklığı ile 25(OH)D vitamini düzeyleri arasında ilişki bulunamamıştır. Bunun sebebi vaka sayısının az olması, mevsimsel farklılık, yaş, beslenmenin, güneş etkilerinin ve giyim tarzının tam olarak değerlendirilememiş olması ile açıklanabilir.

Serum 25(OH)D vitamini düzeylerine ilişkin henüz kesin bir eşik değer tanımlanmamıştır. Fakat birçok araştırmacı $20 \mathrm{ng} / \mathrm{ml}$ altında olan serum 25(OH)D düzeylerini D vitamini eksikliği olarak kabul etmektedirler. Yapılan bir çalışmada; 25(OH)D düzeyinin $20 \mathrm{ng} / \mathrm{ml}$ 'den düşük olması D vitamini eksikliği, 21 ile $32 \mathrm{ng} /$ $\mathrm{ml}$ arasında olması D vitamini yetersizliği, 32 ile $100 \mathrm{ng} / \mathrm{ml}$ arasındaki değerler yeterli D vitamini düzeyi, $150 \mathrm{ng} / \mathrm{ml}$ üstündeki değerler ise $D$ vitamini intoksikasyonu olarak kabul edilmiştir (13). Fakat yinede hangi serum D vitamini düzeyinin üstündeki değerlerin enfeksiyonlara karşı korumada etkili olduğu kesin olarak belli değildir. Bizim araştırmamızda çalışma grubunun serum $25(\mathrm{OH})$ D vitamini düzeyi ortalaması $26,43 \pm 6,05$ olarak saptandı. Kontrol grubunda ise $25(\mathrm{OH}) \mathrm{D}$ vitamini düzeyi ortalaması $37,88 \pm 13,43$ bulundu. Kontrol grubunun ortalama $25(\mathrm{OH})$ $D$ vitamini düzeyleri çalışma grubuna göre anlamlı olarak daha yüksek bulunmuştur. Bizim çalışmamızda da diğer çalışmalara benzer şekilde ASYE geçiren grup ile ASYE geçirmeyen grup arasında 25(OH)D vitamini düzeyleri açısından istatistiksel olarak anlamlı fark olduğunu saptandı. Çin'de yapılan bir çalışmada çocuklarda ASYE'nin 25(OH)D vitamini eksikliği ile ilişkili olduğu gösterilmiştir (14). Wang ve arkadaşları D vitamini tedavisinin AMP gen ekspresyonunu arttırdığını göstermişler ve bu şekilde firsatçı enfeksiyonların tedavisinde D vitamininin kullanılabileceğini belirtmişlerdir (15). Karatekin ve arkadaşlarının yaptıkları çalışmada ise; ASYE geçiren ve raşitik olmayan çocuklarda 25(OH)D vitamini düşüklüğü tespit edilmiştir (16). Bizim bu çaış̧mamızdaki ve yapılan diğer çalışmalardaki verilere dayanarak; $25(\mathrm{OH}) \mathrm{D}$ vitamini düşüklüğünün alt solunum yolu enfeksiyonları için bir risk faktörü olabileceği söylenebilir.

Yaptığımız bu çalışmada; ASYE geçirme sıklığı artmasına rağmen serum 25(OH)D vitamini düzeyleri ortalamasında anlamlı bir azalma görülmemiştir ve ASYE sayısı ile 25(OH)D vitamini düzeyleri arasında istatistiksel olarak anlamlı bir fark saptanmamıştır ( $p=0,852)$. Bu durumu vaka sayısının azlığına, vitamin $D$ düzeyini etkileyen faktörlerden beslenmenin, güneş etkilerinin ve giyim tarzının tam olarak değerlendirilememesine ve hastaların hem yaz hem de kış dönemlerinde toplanmış olmasına bağladık. Sık tekrarlayan ASYE ve 25(OH)D vitamini ile ilgili çok fazla çalışma olmamasına rağmen; sık tekrarlayan ÜSYE ve D vitamini düzeyleri ile ilgili yapılan çalışmalarda D vitamini düzeyinin düşük olması ile ÜSYE sıklığının arttğı gösterilmiştir $(17,18)$. Bu veriler ASYE'nin sık tekrarlamasında D vitamini eksikliği ve yetersizliğinin rolü olabileceğini düşündürmekle birlikte daha çok vaka ile yapılan randomize kontrollü çalışmalara ihtiyaç vardır.

D vitamini düzeyi çevresel ve maternal faktörlerden etkilenmektedir. D vitamini düzeyini etkileyen bu faktörler; yaş, cinsiyet, etnik köken, sosyoekonomik düzey, mevsimsellik, UV-B ışınlarına maruz kalma, Gomez skoru, sağlık durumu, pubertal evre, toplam enerji alımı ve diyet şeklinde sıralanabilir. Bu açıdan çaıışmamızda her iki grubun yaş, cinsiyet, kilo, boy, doğum tartısı, gebelikte D vitamini kullanımı, anne giyim şekli, sadece anne sütü alımı, toplam anne sütü alımı, günlük en az 400 IU düzenli $D$ vitamini kullanımı ve en az 1 yıl süre ile düzenli $D$ vitamini kullanımı açısından istatistiksel olarak anlamlı fark bulunmamıştır.

Yaptığımız araştırmada tüm grupta gebeliğinde $D$ vitaminini düzenli kullanan annelerin çocuklarında serum 25(OH)D vitamini düzeyinin ortalaması $35,50 \pm 12,77$ saptanırken; D vitaminini dü-

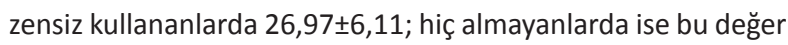
$29,54 \pm 12,09$ saptanmıştır. Düzenli D vitamini alanların çocuklarında diğerlerine göre daha yüksek $25(\mathrm{OH}) \mathrm{D}$ vitamini düzeyleri olmasına rağmen düzensiz kullananlarda hiç kullanmayanlara göre daha düşük $25(\mathrm{OH}) \mathrm{D}$ vitamini düzeyleri bulunmuştur. Bu durum $D$ vitamini düzeyini etkileyen diğer faktörler nedeni ile bu şekilde olmuş olabilir. Annenin D vitamini düzeyi ile bebeğin D vitamini düzeyi arasındaki ilişki açısından yapılmış birçok çalışma bulunmaktadır. Örneğin D vitamininden fakir beslenme ve güneşten sakınma kampanyalarının yoğun olduğu bir bölgede 929 sağlıklı yenidoğanda yapılan bir çalışmada bebeklerin $\% 19$ 'unda kord kanında D vitamini düzeyi $<10 \mathrm{ng} / \mathrm{ml}$, \%57'sinde $<20 \mathrm{ng} / \mathrm{ml}$ ve \%27'sinde $30 \mathrm{ng} / \mathrm{ml}$ bulunmuştur (19). Ülkemizde ise 101 sağlıklı term yenidoğanda kord kanındaki $D$ vitamini düzeyini değerlendiren bir çalışmada, bebeklerin \%31'inde D vitamin eksikligi (<12 ng/ml) saptanmıştır (20). Jonathan ve arkadaşlarının yaptı̆̆ bir araştırmada ise, gebeliğinde $D$ vitamini seviyesi düşük olan annelerin bebeklerinde ilerleyen dönemlerde ASYE sıklığının arttı̆ı gösterilmiştir. Özellikle de kordon kanında D vitamini düşük saptanan bebeklerin ilk 6 ay solunum sistemi hastalıklarını daha çok geçirdikleri gözlenmiştir (21).

Çalışmaya dâhil edilen olgulardan, günlük en az 400 IU D vitamini düzenli kullananların serum $25(\mathrm{OH}) \mathrm{D}$ vitamini düzeyi $37,29 \pm 12,25 \mathrm{ng} / \mathrm{ml}$ iken düzensiz kullananlarda bu düzey $25,95 \pm 7,91 \mathrm{ng} / \mathrm{ml}$ saptanmış ve fark istatistiksel olarak anlamI bulunmuştur. Ülkemizde infantlara proflaktik amaçlı günlük 400 IU D vitamini desteği verilmektedir. Günlük önerilen 400 IU olmasına rağmen son zamanlarda bu miktarın günlük 800-1000 IU olması gerektiğini belirten çalışmalar vardır (22). 
Yaptığımız bu çalışmada hamilelik döneminde ve doğumdan sonra süt çocuklarında düzenli D vitamini kullanımının çocukların 25(OH)D vitamini düzeyini olumlu yönde etkilediği söylenebilir. Çalışmamızda cinsiyet, anne sütü ile beslenme süresi, annenin giyim şekli ve dışarıda zaman geçirme sıkığı ile $25(\mathrm{OH})$ D vitamini düzeyi arasında anlamlı bir ilişki saptanamamıştır. Bunun nedeni, çalışmamızdaki olgu sayısının azlığı, olguların farklı mevsimlerde seçilmiş olması ve çalışmaya dâhil edilen olguların birbiriyle benzer özelliklerde olmaması ile açıklanabilir. Ancak literatürde bunlarla ilgili geniş serileri içeren ve farklı sonuçlar saptayan çok sayıda çalışma bulunmaktadır. Ayrıca çalışmamızda günlük alınan idame dozda $D$ vitamininin, raşitizimden korunmak için yeterli kabul edilen $D$ vitamini düzeylerini sağladığı görülmüştür. Bununla birlikte bu düzeylerin alt solunum yolu enfeksiyonlarından korunmaya yetecek düzeyde olup olmadığının cevabı için verilerimizin yeterli olmadığı, daha geniş kapsamlı ve çok merkezli çalışmalara gereksinim olduğu açıktır.

Sonuç olarak; serum D vitamin düzeyi düşüklüğü çocukluk çağı ASYE için risk faktörü olabileceğinden ASYE olan vakalarda serum 25(OH)D vitamini düzeyi bakılması önerilebilir. Ayrıca enfeksiyon hastalıklarına karşı savunmada rol alan sınır D vitamin düzeyini belirleyebilmek için vaka sayısının daha fazla olduğu klinik-etkinlik araştırmalarına ihtiyaç vardır.

Etik Komite Onayı: Bu çalışma için etik komite onayı alınmıştır.

Bilgilendirilmiş Onam: Katılımcılardan bilgilendirilmiş onam alınmıştır.

Hakem Değerlendirmesi: Dış bağımsız.

Yazar Katkıları: Çalışma Konsepti/Tasarım- N.A., M.Ö.; Veri ToplamaN.A., M.Ö., A.A.; Veri Analizi/Yorumlama- N.A., M.Ö., A.A., N.S., Y.Ç.; Yazı Taslağı- N.A., M.Ö.; İçeriğin Eleştirel İncelemesi- N.A., M.Ö., A.A., N.S., Y.Ç.; Son Onay ve Sorumluluk- N.A., M.Ö., A.A., N.S., Y.C..; Malzeme ve Teknik Destek- N.A.; Süpervizyon- N.A., M.Ö., A.A., N.S., Y.Ç.

Çıkar Çatışması: Yazarlar çıkar çatş̧ması beyan etmemişlerdir.

Finansal Destek: Yazarlar finansal destek beyan etmemişlerdir.

Ethics Committee Approval: Ethics committee approval was received for this study.

Informed Consent: Written consent was obtained from the participants.

Peer Review: Externally peer-reviewed.

Author Contributions: Conception/Design of Study- N.A., M.Ö.; Data Acquisition- N.A., M.Ö., A.A.; Data Analysis/InterpretationN.A., M.Ö., A.A., N.S., Y.Ç.; Drafting Manuscript- N.A., M.Ö.; Critical Revision of Manuscript- N.A., M.Ö., A.A., N.S., Y.Ç.; Final Approval and Accountability- N.A., M.Ö., A.A., N.S., Y.Ç.; Technical or Material Support- N.A..; Supervision- N.A., M.Ö., A.A., N.S., Y.Ç.

Conflict of Interest: Authors declared no conflict of interest.

Financial Disclosure: Authors declared no financial support.

\section{KAYNAKLAR/REFERENCES}

1. Pletz MW, Rohde GG, Welte T, Kolditz M, Ott S. Advances in the prevention, management, and treatment of communityacquired pneumonia. F1000Res 2016;8(5):300.

2. Forster J, Ihorst G, Rieger CH, Stephan V, Frank HD, Gurth H, et al. Prospective population-based study of viral lower respiratory tract infections in children under 3 years of age (the PRI.DE study). Eur J Pediatr 2004;163:709-16.

3. Agency for Healthcare Research and Quality. Healthcare Cost and Utilization Project (HCUP) Nationwide Emergency Department Sample (NEDS) 2008. Rockville, MD: Agency for Healthcare Research and Quality; 2008.

4. Barger-Lux MJ, Heaney RP. Effects of above average summer sun exposure on serum $25 \mathrm{OH}$ vitamin $\mathrm{D}$ and calcium absorption. J Clin Endocrinol Metab 2002;87(11):4952-6.

5. Özkan B. Nutritional rickets. J Clin Res Pediatr Endocrinol 2010;2(4):137-43.

6. Oren $Y$, Shapira Y, Agmon-Levin N, Kivity S, Zafrir Y, Altman A, et al. Vitamin $D$ insufficiency in a sunny environment: $A$ demographic and seasonal analysis. Isr Med Assoc J 2010;12(12):751-6.

7. Holick MF. Vitamin D: Extraskeletal health. Endocrinol Metab Clin North Am 2010;39(2):381-400.

8. Holick MF, Chen TC. Vitamin D deficiency: a worldwide problem with health consequnces. Am J Clin Nutr 2008;87(4):1080-6.

9. S. Currie, Findlay EG, Mchugh BJ, Mackellar A, Man T, Macmillan $D$, et al. The human cathelicidin LL-37 has antiviral activity against respiratory syncytial virus. PLoS One 2013;8:e73659.

10. Dabrowska-Leonik N, Bernatowska E, Pac M, Filipiuk W, Mulawka $\mathrm{J}$, Pietrucha B, et al. Vitamin D deficiency in children with recurrent respiratory infections, with or without immunoglobulin deficiency. Adv Med Sci 2018;63(1):173-8.

11. Adams JS, Hollis BW. VitaminD: Synthesis, metabolism and clinical measurement. In: Coe FL, Favus MJ, editors; Disorders of bone and mineral metabolism, 2th edition, Philadelphia, Lippincott Williams \& Wilkins, 2002;157-74.

12. Brance ML, Miljevic JN, Tizziani R, Taberna ME, Grossi P, Toni P, et al. Serum 25-hydroxyvitamin D levels in hospitalized adults with communityacquired pneumonia. Clin Respir J 2018;12(7):2220-7.

13. Holick MF. Vitamin D status: measurement, interpretation, and clinical application. Ann Epidemiol 2009;19:73-8.

14. Li W, Cheng X, Guo L, Li H, Sun C, Cui X, et al. Association between serum 25-hydroxyvitamin $D$ concentration and pulmonary infection in children. Medicine Baltimore 2018;97(1):e9060.

15. Wang TT, Nestel FP, Bourdeau V, Nagai Y, Wang Q, Liao J, et al. Cutting Edge: 1,25-Dihydroxyvitamin D3 is a directinducer of antimicrobial peptide gene expression. J Immunol 2004;173:2909-12.

16. Karatekin G, Kaya A, Salihoğlu O, Balci H, Nuhoğlu A. Association of subclinical vitamin $D$ deficiency in newborns with acute lower respiratory infection and their mothers. Eur J Clin Nutr 2009;63:473-7.

17. Yildiz I, Unuvar E, Zeybek U, Toptas B, Cacina C, Toprak S, et al. The role of vitamin $D$ in children with recurrent tonsillopharyngitis. Ital J Pediatr 2012;38(1):25.

18. Ginde AA, Mansbach JM, Camargo CA. Association between serum 25-hydroxyvitamin $D$ level and upper respiratory tract infection in the Third National Health and Nutrition Examination Survey. Arch Intern Med 2010;169(4):384-90. 
19. Camargo CA, Ingham T, Wickens K, Thadhani RI, Silvers KM, Epton $\mathrm{MJ}$, et al. The New Zealand Asthma and Allergy Cohort Study Group. Br J Nutr 2010;104:1051-7.

20. Güven A, Ecevit A, Tarcan A, Tarcan A, Özbek N. Yenidogan bebeklerde kordon kanı vitamin $D$ düzeyleri. Çocuk Saglıgı ve Hastalıkları Dergisi 2011;54:55-61.

21. Lai SH, Liao SL, Tsai MH, Hua MC, Chiu CY, Yeh KW, et al. Low cord-serum 25-hydroxyvitamin D levels are associated with poor lung function performance and increased respiratory infection in infancy. PLoS One 2017;12(3):e0173268.
22. Wagner CL, Greer FR. American Academy of Pediatrics Section on Breast feeding; American Academy of Pediatrics Committee on Nutrition Pediatrics. Prevention of rickets and vitamin D deficiencyin infants, children, and adolescents. Pediatrics 2008;122:1142-52. 